\title{
ON SOME PROBLEMS WITH BREASTFEEDING OF INFANTS
}

\author{
Turnovska T., R. Vasileva, V. Atanasova, P. Gatzeva, G. Kavlakov, \\ At. Alexandrova, G. Mihailova
}

\author{
Department of Hygiene and Ecomedicine, Medical University, Plovdiv
}

\author{
Reviewed by: Assoc. Prof. B. Varbanova
}

\begin{abstract}
The aim of the present study is to analyze breastfeeding with children from the city of Plovdiv. Material and methods: The initial information was collected in the month of June 2005 through a retrospective passive survey conducted with 200 mothers whose children attended 2 day care centers and 2 kindergartens in the city of Plovdiv. The survey questionnaire formulated by the research team included two sets of questions: Relating to the mother and relating to the child. Results: At the time of giving birth to the children participating in the survey, the greatest relative share was of mothers at the age of 24 to $30(64.21 \%)$, followed by those at the age of 31-35-8.95\%. According to their level of education, the highest percentage is of mothers with secondary $(55.7 \%)$ and higher $(41.58 \%)$ education; there are no mothers with elementary education, and those without any school attendance are $1.58 \%$. Only $4(2.10 \%)$ of the surveyed women did not breastfeed their children at all. $68.95 \%$ of the surveyed women claim that they do not know anything about the 'exclusive breastfeeding' method which is recommended by WHO. The most frequent reason for the mothers to cease breastfeeding was insufficiency of breast milk - in $\mathbf{2 6 . 8 4 \%}$ of the cases, followed by 'Others' $\mathbf{- 1 1 . 5 \%}$, 'Health problems of the mothers' - 3.16\%, 'The infant consistently did not gain enough weight' $-1.05 \%$, etc. The average anthropometric indicators of the children (both at the time of birth, and the current readings) correspond to Bulgarian standards. Conclusions: 1.Almost all mothers taking part in the survey $(97.89 \%)$ wanted to and started to breastfeed their infants. The main reason for the discontinuance of breastfeeding is the insufficient amount of their breast milk. 2 . The relative share of the mothers who did not feel prepared for breastfeeding is large. 3. There is evidence that the medical workers in the birth preparation centers have unsatisfactory knowledge of the current recommendations of the WHO in the sphere of breastfeeding. 4. The 'exclusive breastfeeding' method is not sufficiently well-known and it is not applied.
\end{abstract}

Key words: infants, exclusive breastfeeding

An infant's feeding predetermines to a great extent the health status of a child not only before reaching one year of age, but also afterwards, to a considerable extent. Studies show that breastfeeding lowers the risk of contracting a number of infectious diseases, including bacterial meningitis $(9)$, diarrhea $(8,18)$, respiratory-tract infections $(7,13)$, allergic diseases (21), etc. This is owing to the presence of various anti-infective factors in breast milk - immunoglobulin (Ig A, Ig M), phagocytes, T-cells, lysozyme, lactoferrin, etc., which increase a breast-fed child's immunity (11). A decrease in morbidity also leads to a decrease in child mortality (14). Breastfeeding is a prerequisite for a child's better physical and mental development $(16,22)$. Breast-fed children have been reported to be at a lower risk of arterial hypertension (17) and obesity (6) at a later stage in life.

Address for correspondence:

T. Tarnovsk, Section Hygiene and Ecomedicine; Medical university, Plovdiv; Vasil Aprilov Blv. 15 A

e-mail: turnovt@yahoo.com
Undoubtedly there are numerous benefits from breastfeeding for mothers as well - quicker recovery after giving birth (12), less risk of breast cancer, ovarian cancer, risk of rheumatoid arthritis (19) etc.

The American Academy of Pediatrics also stresses the advantages of breastfeeding for society - reduction in health care expenditure, funding of programs connected with women's and children's nutrition, a decrease in parents' absences from work, reducing expenses on transportation of special foods for children, energy for producing them, transportation and making their packaging safe, etc. (10). Despite the numerous advantages of breastfeeding, evidence shows it is not typical of American culture (15). The American Academy of Pediatrics reports that, with regard to scope and duration, breastfeeding in the USA is considerably below The Aims of Healthy People 2010 program (23). In contrast, breastfeeding is typical of Bulgarian culture. However, the socio-economic changes during the period of transition to market economy had a negative effect on the nutrition model of the majority of the Bulgarian population. The existing lack of balance in the nutrition of the population creates the possi- 
bility of a rise in states of malnutrition amongst large groups of the population, including amongst expectant mothers. National studies show that milk and dairy-products consumption amongst them is insufficient $(1,4)$. This is directly associated with the reported problems with breastfeeding - only $30 \%$ of infants are breastfed for 6 months (2), and the significance of breastfeeding for this period of development of the infant is well-recognized $(20,5)$. In connection with this, the so-called method of 'exclusive breastfeeding' became extremely popular. For the present research we set as a goal to analyze breastfeeding with children from the city of Plovdiv.

\section{MATERIAL AND METHODS}

The initial information was collected in the month of June 2005 through a retrospective passive survey conducted with 200 mothers whose children attended 2 day care centers and 2 kindergartens in the city of Plovdiv. The survey was carried out with the assistance of the nurses working at the day care centers and kindergartens. In order to avoid accidental errors in the entering of the children's anthropometric indicators, the survey was not anonymous. The survey questionnaire formulated by the research team included two sets of questions: 1 . Relating to the mother: 'Did you experience any complications during your pregnancy and during the delivery of this child?, How many hours after giving birth were you given your infant to breastfeed it?, Were you prepared for successful breastfeeding?, Are you familiar with the 'exclusive breastfeeding' method?, Did you encounter any problems with breastfeeding?, What was the duration of a breastfeeding session?, How many months did you breastfeed your child?, What kind of reasons made you stop breastfeeding?', etc. and 2. Relating to the child: 'If the child was not breastfed, what kind of food was it fed?, In which month did you substitute one of the breastfeeding sessions with other food?, How many times was the infant sick in the first year of its life?, What kinds of illnesses did the infant suffer from in the first year of its life?, At what rate did your baby gain weight in the first year of its life?, When did the child cut its first teeth?, At what age did the child start walking?, At what age did the child utter its first sentence?', etc. Analysis of variance, correlation, alternative, and graphic analyses were used in the statistical processing of the results.

\section{RESULTS AND DISCUSSION}

The usable survey questionnaire forms are 190, where some questions lack answers in some of the survey forms. At the time of giving birth to the children participating in the survey, the greatest relative share was of mothers at the age of 24 to $30(64.21 \%)$, followed by those at the age of $31-35-8.95 \%$. According to their level of education, the highest percentage is of mothers with secondary $(55.79 \%)$ and higher (41.58\%) education; there are no mothers with elementary education, and those without any school atten- dance are $1.58 \%$. Only 4 (2.10\%) of the surveyed women did not breastfeed their children at all. The majority of the mothers did not have any complications during pregnancy and delivery $-82.63 \% .43 .68 \%$ of the surveyed mothers were given their children six hours after birth, and $46.31 \%$ between the 5th and 6th hour. Most of the mothers $(65.26 \%)$ did not have problems during breastfeeding (mastitis, rhagades, general somatic illnesses, etc.), nevertheless, only with $12.11 \%$ of them it lasted $20-30 \mathrm{~min}$. In the majority of cases $(56.32 \%)$ a breastfeeding session was 10-20 min. long, and with $18.95 \%$ - no more than $10 \mathrm{~min}$. In contrast to this, the answers to the question: 'Were you sufficiently prepared for successful breastfeeding before giving birth?' yielded a high percentage of negative answers $-38.95 \%$. Obviously the majority of the mothers $(57.37 \%)$ felt prepared; the number of those who did not know how long a breastfeeding session should last, is not small either. Keeping in mind the high level of education of the surveyed women, which might allow us to presuppose certain amount of self-preparation with a number of them, we consider the comparatively large number of mothers who were unprepared for breastfeeding to be a result of serious failures in the work of the birth preparation centers. In support of this, $68.9 \%$ of the surveyed women claim that they do not know anything about the 'exclusive breastfeeding' method which is recommended by WHO. In order to 'check' the veracity of the answers, we also asked the question: 'When the infant was only breastfed, did it receive any other liquids - tea, water?' Only $4.74 \%$ of the mothers said: 'No'. This demonstrates that the $28.95 \%$ of them, claiming to be familiar with the mentioned method, probably were not sufficiently convinced of its correctness, since they did not put it into practical use. This makes us conclude that it is possible for the level of knowledge of doctors and maternity nurses caring for pregnant women to be low, or not to be updated regularly. The fact that $78.42 \%$ of the mothers substituted one of the breastfeeding sessions with some other food between the $4^{\text {th }}$ and $6^{\text {th }}$ month means that the majority of them adhered to the standard infant-feeding scheme established in Bulgaria. It has to be noted though, that with $1.58 \%$ of the infants the first substituted breastfeeding session occurred between the $9^{\text {th }}$ and $12^{\text {th }}$ month, and with $0.53 \%>$ even after the first year. The most frequent reason for the mothers to cease breastfeeding was insufficiency of breast milk - in $26.84 \%$ of the cases, followed by 'Others' - $11.5 \%$, 'Health problems of the mothers' $-3.16 \%$, 'The infant consistently did not gain enough weight' $-1.05 \%$, etc.

The main anthropometric indicators of the children taking part in the survey are presented in Table 1. It shows that the average indicators both at the time of birth, and the current readings (in the month of June 2005) correspond to Bulgarian standards (3). However, seven of the children (3.68\%) were prematurely born (body mass under $2500 \mathrm{~g}$ ), and 2 of them were respectively 1500 and $1580 \mathrm{~g}$. In order to estimate the significance of breastfeeding with prematurely born children, we analyzed the individual development and health status of each one of them. The findings showed that 
the current height and body mass of 1 of these children (born weighing $2100 \mathrm{~g}$ ) corresponded to Bulgarian standards $(X \pm S D)$, which for the age of 5 years and 6 months is $115 \mathrm{~cm}$ and $19 \mathrm{~kg}$.

Table 1. Anthropometric indicators of the children taking part in the survey

\begin{tabular}{|c|c|c|c|c|c|c|}
\hline $\begin{array}{l}\text { Indi- } \\
\text { cators }\end{array}$ & $\begin{array}{c}\text { Statist. } \\
\text { para- } \\
\text { meters }\end{array}$ & $\begin{array}{l}\text { Altoget } \\
\text { her for } \\
\text { the } \\
\text { group }\end{array}$ & $\begin{array}{c}8-35 \\
\text { months }\end{array}$ & $\begin{array}{c}\text { 36-72 } \\
\text { months }\end{array}$ & Boys & Girls \\
\hline \multirow{2}{*}{$\begin{array}{l}\text { Height } \\
\text { at the } \\
\text { time of } \\
\text { birth }\end{array}$} & $X$ & 50.1 & 50.21 & 50.03 & 50.06 & 50.13 \\
\hline & SD & 2.75 & 1.86 & 3.15 & 2.61 & 2.89 \\
\hline \multirow{2}{*}{$\begin{array}{l}\text { Body } \\
\text { mass at } \\
\text { the time } \\
\text { of birth }\end{array}$} & $X$ & 3254 & 3365 & 3191 & 3334 & 3175 \\
\hline & SD & 515 & 452 & 540 & 544 & 476 \\
\hline \multirow{2}{*}{$\begin{array}{l}\text { Current } \\
\text { height }\end{array}$} & $X$ & 101.59 & 91.09 & 108.13 & 101.71 & 101.46 \\
\hline & SD & 11.88 & 6.62 & 9.5 & 9.7 & 13.94 \\
\hline \multirow{2}{*}{$\begin{array}{l}\text { Current } \\
\text { body } \\
\text { mass }\end{array}$} & $X$ & 16.79 & 13.94 & 18.53 & 16.97 & 16.62 \\
\hline & SD & 4.27 & 2.35 & 4.25 & 3.77 & 4.74 \\
\hline
\end{tabular}

The child's mother has secondary education, she did not experience any complications during the time of pregnancy and labor, a breastfeeding session lasted 10-20 min., and she adhered to the breastfeeding regime; the child nursed for 6 months, from the 4th month it was additionally formula-fed, it was sick with respiratory-tract illnesses up to 2 times in the 1st year of its life. Of the other 6 children, 5 are 'above or below norm' with regard to their body mass (underdevelopment with more than 2 SD), and the 6 th child falls in 'extended norm' (up to - 2 SD). These children nursed 3 to 6 months, additionally formula-fed (one of them also fed with yoghurt). Two of the children were sick on more than 4 occasions in the first year of their lives, mainly with respiratory-tract and allergic illnesses. The other 4 children were sick no more than 2 times. From the group of the prematurely born children, 4 started walking some time between the $9^{\text {th }}$ and the $12^{\text {th }}$ month, and two - between the $13^{\text {th }}$ and the $18^{\text {th }}$ month. Teething was 'late' with 3 of these children - after the $9^{\text {th }}$ month. All seven children started talking before the end of their second year of life. It is rather impressive that the mothers regard their preparation for breastfeeding as insufficient. It is a paradox that according to 2 of them their children gained weight well. This shows not only the lack of good contact between the mothers and the birth preparation centers but also the absence of such contact with the child-monitoring centers. Obviously the prematurely-born children, though breastfed in the first few months of their lives, did not manage to make up the underdevelopment in their physical growth and biological maturity, which is indicated by the late teething and beginning of walking with some of them.

\section{CONCLUSIONS}

1. Almost all mothers taking part in the survey $(97.89 \%)$ wanted to and started to breastfeed their infants. The main reason for the discontinuance of breastfeeding is the insufficient amount of their breast milk.

2. The relative share of the mothers who did not feel prepared for breastfeeding is large.

3. There is evidence that the medical workers in the birth preparation centers have unsatisfactory knowledge of the current recommendations of the $\mathrm{WHO}$ in the sphere of breastfeeding.

4. The 'exclusive breastfeeding' method is not sufficiently well-known and it is not applied.

\section{LITERATURE}

1. Байкова, Д., С. Петрова, К. Ангелова и др. Прием на белтък. В: Национално проучване на храненето и хранителния статус на населението в България, 1998 година (Петрова С. и кол.).

Хигиена и здравеопазване, 2000, 3-4.

2. Доклад за здравето на нацията в началото на 21 век. Анализ на провежданата реформа в Здравеопазването. Министерство на здравеопазването, Август, 2004, стр. 68.

3. Методика за провеждане на профилактични прегледи за лица от 0-18 год. ДВ бр. 16/2003, стр.32.

4. Петрова, С., Д. Байкова, К. Ангелова, Л. Иванова, В. Дулева, М. Янчева. Хранителна консумация на населението в България. Хигиена $и$ здравеопазване, 2000, 1, 22-25.

5. American Academy of Pediatrics, Committee on Nutrition. Brestfeeding. In: Kleinman RE, ed. Pediatric Nutrition Handbook. $5^{\text {th }}$ ed. Elk Grove Village, IL: American Academy of pediatrics, 2004, 55-85.

6. Arenz S, Ruckerl R, Koletzko B, von Kries R. Breast-feeding and childhood obesity - a systematic review. Int J Obes Relat Metab Disord, 28, 2004, $10,1247-1256$.

7. Blaymore Bier J, Oliver T, Fergusen A, Vorhr BR. Human milk reduces outpatient upper respiratory symptoms in premature infants during their first year of life. J Perinatal, 2002, 22, 354-359.

8. Dewey KG, Heinig MJ, Nommsen-Rivers LA. Differences in morbidity between brest-fed and formula-fed infants. J Pediatr, 1995, 126, 696-702.

9. Heinig MJ. Host defense benefits of breastfeeding for the infant. Effect of breastfeeding duration and exclusivity. Pediatr Clin North Am, 2001, 48, 105-123.

10. Jarosz LA. Brest-feeding versus formula: cost comparison. Hawaii Med J, 1993, 52, 14-18.

11. Lawrence R, Lawrence R. Breastfeeding: a Guide for the Medical Profession. St. Louis, MO: Mosby, 1999. 
12. Labbok MH. Effects of brestfeeding on the mother. Pediatr Clin North Am, 2001, 48, 143-158.

13. Lopez-Alarcon M, Villalpando S, Fajardo A. Brest feeding lowers the frequency and duration of acute respiratory infection and diarrhea in infants under six months of age. J Nutr, 1997, 127, 436-443.

14. Newton ER. Physiology of lactation and breast-feeding. In: Gabbe SG, Niebyl JR, Simpson JL, eds. Obstetrics: Normal and Problem Pregnancies. Philadelphia, PA: Churchill Livingstone, 2002, 105-136.

15. Nelsen J, Return to Work: Practical Management of Breastfeeding, Clinical Obstetrics and Ginecology,47, 2004, 3, 724-733.

16. Newton DR, Breastmilk: The Gold Standard, Clinical Obstetrics and Gynecology, 47, 2004, 3, 632-642.

17. Owen CG, Whincup PH, Gilg JA, Cook DG. Effect of breast feeding in infancy on blood pressure in later life: systematic review and meta-analysis. BMJ, 2003, 22, 327, 1189-1195.
18. Popkin BM et al. Brestfeeding and diarrheal morbidity. Pediatrics, 1990, 86, 874-882.

19. Rea MF. [Benefits of breastfeeding and women's health] [Article in Portuguese]. J Pediatr (Rio J). 2004 Nov;80(5 Suppl):S 142-146.

20. Schanler A. et al. Feeding strategies for premature infants: beneficial outcomes of feeding fortified human milk versus preterm formula. Pediatrics, 1999 , 103, 1150-1157.

21. Thompson J. Breastfeeding: benefits and implications. Part two. Community Pract. 78, 2005, 6, 218-219.

22. Tully MR. Recommendations for handling of mother's own milk. J Hum Lact, 2000, 16, 149-151.

23. US Department of Health and Human Services. Healthy people 2010: Conference Ediriion, v.I and II. Washington, DC: US Department of Health and Human Services, Public Health Service, Office of the Assistant Secretary for Health, 2000, 47-48.) 